\title{
FACTORS AFFECTING CAPITAL EXPENDITURES AND COMMUNITY WELFARE IN KALIMANTAN
}

\author{
Helma Malini \\ Universitas Tanjungpura \\ Email: helma.malini@untan.ac.id
}

\begin{abstract}
From centralized to decentralized systems provides new hope for most provinces in Indonesia. With government decentralization, it means that management authority will be distributed from the center to the regions. This study aims to examine and prove whether Locally-Generated Revenue (Pendapatan Asli Daerah-PAD), Special Allocation Fund (Dana Alokasi Khusus-DAK), General Allocation Fund (Dana Alokasi Umum-DAU), ProfitSharing Fund (Distribusi Bagi Hasil-DBH) affect capital expenditure and community welfare in Kalimantan. The population in this study are districts and cities in Kalimantan, consisting of 47 districts and 9 cities. The method used to determine the sample is purposive sampling, which selects samples with certain criteria. From a population of 56, this study examines a sample of 49 observations (42 districts and 7 cities). The results show that PAD, DAK, $D A U$, and DBH positively impact capital expenditure in Kalimantan. However, capital expenditure has no effect on community welfare in Kalimantan.
\end{abstract}

Keywords: Kalimantan, Capital Expenditure, Community Welfare, Centralize, Decentralize

\section{INTRODUCTION}

Economic development is often distinguished from economic growth. Economic growth involves increasing the output of goods and services, but development has a broader meaning. Changes in the distribution of wealth and income among various groups of economic actors are all part of the development process (Rostow \& Rostow, 1990; Verspagen, 2005).

The concept of social welfare refers to a country's system of benefits and services to assist the community in obtaining social, economic, educational, and health needs that are critical to the community's survival. Lack of ability in the case of low welfare can mean that you are unable to perform certain functions, making you less prosperous. Because welfare is more subjective, each person with different guidelines, goals, and ways of life will assign different values to welfare and the factors that determine its level (Lamba et al., 2020; Muda \& Naibaho, 2018; Wulandari et al., 2018).

Information on community welfare development is an important input in the development planning process. Several well-being indicators have been developed to aid in observing patterns of disparities in community well-being between regions. The Human Development Index (HDI) as a welfare indicator is now widely accepted worldwide, and it has even gained regional acceptance. Human development can be defined as a process that broadens options for meeting basic human needs in economics (purchasing power), health, and education (Sagar \& Najam, 1998).

Regarding economic development, the relationship between the federal government and local governments and the private sector should be managed appropriately, with the private sector assisting in the implementation of economic development. Another important development is regional development, a process between local government and community that involves managing potential and resources owned by each blood and fostering private-sector cooperation (Muda \& Naibaho, 2018). 
West Kalimantan, Central Kalimantan, South Kalimantan, East Kalimantan, and North Kalimantan are all parts of the Indonesian island of Kalimantan. Table 1 shows that total gross regional domestic product (GRDP) per capita in Kalimantan Island increased the most in 2018 (188.70 billion rupiahs) and the least in 2014 (174.52 billion rupiahs). However, when looking at the average GRDP per capita in Kalimantan Island by region, there are four provinces, namely West Kalimantan (22.52 billion rupiahs), Central Kalimantan (29.23 billion rupiahs), South Kalimantan (24.85 billion rupiahs), and North Kalimantan (33.98 billion rupiahs), while East Kalimantan has the highest average GRDP per capita (71.89 billion rupiahs). Due to income from the mining sector, several provinces in Kalimantan have a high GDRP. On the other hand, the number of foreign investments is increasing due to the local government's ability to attract investors through various investment policies (Statistics Indonesia, 2019).

Table 1. GRDP Per-Capita Between Provinces in Kalimantan 2014-2018 (billion rupiahs)

\begin{tabular}{ccccccc}
\hline \multirow{2}{*}{ Province } & \multicolumn{5}{c}{ Year } & \multirow{2}{*}{ Average } \\
\cline { 2 - 6 } & $\mathbf{2 0 1 4}$ & $\mathbf{2 0 1 5}$ & $\mathbf{2 0 1 6}$ & $\mathbf{2 0 1 7}$ & $\mathbf{2 0 1 8}$ & \\
\hline West Kalimantan & 22.70 & 23.09 & 23.22 & 23.12 & 22.52 & 22.52 \\
Central Kalimantan & 26.71 & 28.03 & 29.33 & 30.47 & 31.63 & 29.23 \\
South Kalimantan & 22.63 & 23.74 & 24.85 & 25.97 & 27.04 & 24.85 \\
East Kalimantan & 71.63 & 72.39 & 72.29 & 72.38 & 70.76 & 71.89 \\
North Kalimantan & 30.85 & 32.41 & 34.01 & 35.87 & 36.75 & 33.98 \\
Kalimantan (Total) & 174.52 & 179.66 & 183.70 & 187.81 & 188.70 & 182.88 \\
\hline
\end{tabular}

Source: Statistics Indonesia (2019)

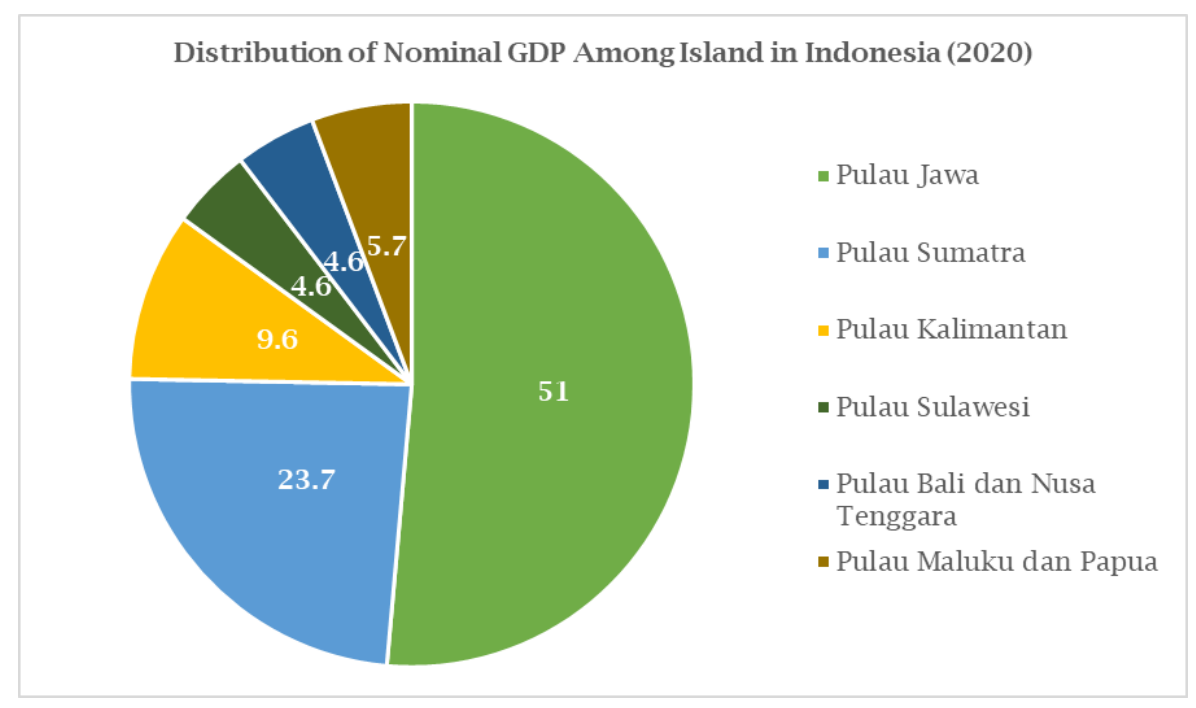

Figure 1. Distribution of Nominal GDP Among Island in Indonesia (2020)

According to Figure 1, the GDP distribution in Indonesia is concentrated in Java and Sumatera Islands. This graph shows that economic growth in certain islands is influenced by their ability to benefit from the decentralized system in Indonesia. The islands of Kalimantan and Sulawesi are among those with a low percentage of GDP distribution. A study published by Asari and Suardana (2018) showed that the ability of each province in Indonesia to generate income and improve community welfare is dependent on the governor's policy of allocating budget based on a priority scale. On the other hand, a study conducted by Saraswati and Rioni (2019) showed that one province's spending significantly impacts economic growth in Indonesia. This vicious cycle resulted in economic growth and had an impact on the GDP of provinces in general.

It is critical to determine whether one province in Indonesia can compete with other provinces with regard to capital expenditures and increasing community welfare. This study determines whether one province concentrated in an island with a wide population 
and income distribution, such as Kalimantan, can compete with other Island provinces regarding capital expenditures and increasing community welfare. This study contributes to whether a province can manage the income and income allocation through the mechanism of autonomy, which can help related parties determine the best policies for related provinces, particularly in Kalimantan Island.

\section{LITERATURE REVIEW}

Planning is an indispensable component of any organization's decision-making process. Additionally, the budget occupies a highly significant position. When an organization's resources are acquired and used, a budget is a detailed plan formally stated in quantitative terms, usually in units of money (financial planning), to show the acquisition and use of those resources (Saraswati \& Ramantha, 2018). According to Fatimah et al. (2019), the public budget contains activity plans represented in income and expenditure acquisition plans in monetary units described in the form of income and expenditure acquisition plans in monetary units. Within a specific period, a regional budget is a financial operating plan that includes an estimate of the proposed expenditure and the expected sources of revenue to finance regional expenditures within that period. The regional budget is one tool that can be used to make significant improvements in public services.

The primary goal of the budget formulation process is to translate the government's economic planning, which is comprised of input and output planning, into monetary terms. The budget operates in the following ways: (1) the budget is the final product of developing a work plan; (2) the budget serves as an internal communication tool, linking various work units and work mechanisms between superiors and subordinates; (3) the budget as a tool for controlling work units; and (4) a budget is a tool for fiscal policy implementation. Budget as an instrument of economic policy can be interpreted in the following ways: (1) the direction of the economic program in the exploration of natural resources; (2) establishing a macroeconomic equilibrium; and (3) resources are distributed equitably. It is necessary to organize the budget so that the overall impact on the economy can be measured. When it comes to government management, the economic function should be linked to development planning, assist the central bank in assessing the impact of credit and financial policies, and facilitate government administration by maintaining a balance between cash and management (Pratiwi et al., 2018).

The budget process should begin with the establishment of goals, targets, and policies. For the budget to be successful, it is critical that all parties have a common understanding of what is expected to be accomplished and that the objectives are relevant to the various programs that will be implemented. The following are some examples of the budget's role and relationship to the management process in the organization: (1) developing policies and strategic planning; (2) calculate income and expenses; (3) give approval for future expenses; (4) provide a foundation for tracking and reporting income and expenses; (5) coordination of the activities of the various organizational functions; (6) motivating managers and business owners; and (7) develop standards for job performance evaluation (Syafira, 2020).

Capital expenditure is a term that refers to the expenditure of money on capital projects. According to Andriani and Wahid (2018), region-wide expenditures are defined as all expenditures from the regional general treasury account that reduce the equity of funds in a fiscal year and will not be repaid, which are defined as regional obligations in that fiscal year and will not be repaid. According to Saraswati and Rioni (2019), capital expenditure is a budget expenditure for acquiring fixed assets and other assets that provide benefits over a longer period than the period in which the expenditure is made. It is necessary to understand the definition of fixed assets or other assets, as well as the criteria for capitalization of fixed assets, to determine whether a particular expenditure can be classified as capital expenditure or not. Fixed assets must be tangible, contribute 
to the government's assets, have a useful life of more than one year, and have a relatively significant value compared to other assets. While the criteria for other assets are intangible, they must also contribute to government assets, have a useful life of more than one year, and have a significant monetary value relative to other assets.

It has been shown that the grant of regional autonomy impacts economic growth in a region because it gives local governments the freedom to manage and plan their financial budgets and implement policies that can affect the progress of a region. It can provide new hope for the optimal growth of regional development, which is no longer confined to the center of the country. Regional autonomy opens the door to the broadest possible range of regions to realize their best potentials optimally. As a result, each region must have one or several distinct advantages over the other regions to compete (Fatimah et al., 2019; Heryanti et al., 2019; Kadafi, 2013).

\section{Hypotheses Development}

\section{Locally Generated Revenue and Capital Expenditure}

Locally Generated Revenue (Pendapatan Asli Daerah-PAD) is the pure income from a region. Fiscal decentralization empowers regions to manage and regulate all government affairs while increasing local communities' participation, initiatives, and empowerment. The ability of the region to generate regional revenue is highly dependent on the ability to realize the economic potential of the local area (Saraswati \& Ramantha, 2018). Regions with adequate facilities and infrastructure will affect community productivity, attract investors, and ultimately increase PAD. Increased PAD should be able to raise capital expenditure. Thus, the hypothesis is developed as follows.

H1: PAD affects capital expenditures in Kalimantan.

\section{Special Allocation Funds and Capital Expenditure}

According to the functions that embody government duties in certain fields, the Special Allocation Funds (Dana Alokasi Khusus-DAK) are intended to fund special regional and national priorities to meet basic public service and infrastructure needs. Not all regions will get DAK funding. DAK will be allocated to only a select number of regions each year based on the criteria. Public service, defense, order, security, economy, environment, housing, public facilities, health, tourism, religion, education, and social security are all examples of areas where capital expenditures are made (Eksandy et al., 2019). The proper application of capital expenditure results in economic prosperity. As a result, the hypothesis is developed as follows.

H2: DAK affects capital expenditures in Kalimantan.

\section{General Allocation Funds and Capital Expenditure}

One of the balancing funds is General Allocation Funds (Dana Alokasi Umum-DAU). The balancing fund is budgeted to help the regions fund their authority and bridge the funding gap between the regions and the center. DAU is APBN revenues allocated to regions to equalize financial capacity and fund regional decentralization needs. Provinces and districts/cities receive DAU (Pratiwi et al., 2018). The government is still working on rebalancing development funds, especially for marginalized areas. Capital expenditures are made to improve the lives of the locals. Thus, the hypothesis is developed as follows.

H3: DAU affects capital expenditure in Kalimantan.

\section{Profit-Sharing Funds and Capital Expenditure}

Profit-Sharing Fund (Distribusi Bagi Hasil-DBH) is a potential source of regional income for obtaining development funds and regional meeting expenditures not derived from PAD other than DAK and DAU. The income received is based on the producing area. It helps develop the area. Capital expenditure development seeks to improve the area's welfare. Thus, the hypothesis is formulated as follows.

H4: DBH affects capital expenditures in Kalimantan. 


\section{Capital Expenditure and Community Welfare}

Capital expenditures are budgets issued by the government to purchase fixed assets and other assets with a useful life of one accounting period or less that are not intended for resales, such as land and buildings. Buildings, land, and other assets that are used for government services are extremely pro-community in nature. The availability of public services makes life easier for community members (Asari \& Suardana, 2018). Thus, the hypothesis is formulated as follows.

H5: Capital expenditure affects community welfare in Kalimantan.

\section{METHOD}

\section{Data}

The population in this study are districts and cities in Kalimantan, consisting of 47 districts and 9 cities. The method used to determine the sample is purposive sampling, which selects samples with certain criteria. From a population of 56, this study only examines a sample of 49 observations (42 districts and 7 cities) that fit the criteria. The criteria are districts and cities in Kalimantan that have complete 6-year Budget Realization Reports (2013-2018) and districts and cities that have complete Human Development Index (HDI) data for 6 years (2013-2018).

\section{Research Variables}

The research variables used in this study are classified into two dependent variables and four independent variables. The dependent variable used in this study is Capital Expenditure (Belanja Modal-BM) and Community Welfare (Kesejahteraan Masyarakat$K M)$. The independent variables used in this study are Locally-Generated Revenue (Pendapatan Asli Daerah-PAD), Special Allocation Funds (Dana Alokasi Khusus-DAK), General Allocation Funds (Dana Alokasi Umum-DAU), and Profit-Sharing Fund (Distribusi Bagi Hasil-DBH).

\section{Panel Data Regression Analysis}

Hypothesis testing can be done using panel data regression analysis, which aims to predict the strength of the influence of how the independent variable is on the dependent variable (Sugiyono, 2014). This analysis is used to determine and see whether there is an effect of Locally-Generated Revenue (Pendapatan Asli Daerah-PAD), Special Allocation Fund (Dana Alokasi Khusus-DAK), General Allocation Fund (Dana Alokasi Umum-DAU), Profit-Sharing Fund (Distribusi Bagi Hasil-DBH) on Capital Expenditure (Belanja Modal-BM) and Community Welfare (Kesejahteraan Masyarakat-KM). All analyzes carried out in this study will be processed using EViews 9.0 software. The following is a panel data regression model used in this study:

The panel data regression models are:

$$
\begin{aligned}
& B M_{i t}=\alpha+\beta_{1} P A D_{i t}+\beta_{2} D A K_{i t}+\beta_{3} D A U_{i t}+\beta_{4} D B H_{i t}+\varepsilon \\
& K M_{i t}=\alpha+\beta_{1} B M_{i t}+\varepsilon
\end{aligned}
$$

Equation (1) is used to examine the impact of Locally-Generated Revenue (Pendapatan Asli Daerah-PAD), Special Allocation Fund (Dana Alokasi Khusus-DAK), General Allocation Fund (Dana Alokasi Umum-DAU), Profit-Sharing Fund (Distribusi Bagi HasilDBH) on Capital Expenditure (Belanja Modal-BM) of districts and cities in Kalimantan $i$ at a particular time $t$. While Equation (2) is used to examine the impact of Capital Expenditure (Belanja Modal-BM) on Community Welfare (Kesejahteraan Masyarakat$K M)$. 


\section{RESULTS AND DISCUSSION}

The result of model selection with the Chow Test is presented in Table 2.

Table 2. Results of Model Selection with the Chow Test

\begin{tabular}{lccc}
\hline \multicolumn{1}{c}{ Model } & Chow Test & Probability & Model Fitness Test \\
\hline Equation (1) & 189.505865 & 0.0000 & Rejecting Fixed Effect \\
Equation (2) & 125.975496 & 0.0000 & Rejecting Fixed Effect \\
\hline
\end{tabular}

Table 2 shows that the Fixed Effect model is not good to estimate. The result concluded that the fixed-effect model is not good enough for estimation. Table 3 shows the results of model selection using the Hausman Test.

Table 3. Results of Model Selection using the Hausman Test

\begin{tabular}{lccc}
\hline \multicolumn{1}{c}{ Model } & Hausman Test & Probability & Model Fitness Test \\
\hline Equation (1) & 56.080345 & 0.0000 & Accepting Random Effect \\
Equation (2) & 0.475159 & 0.4906 & Accepting Random Effect \\
\hline
\end{tabular}

Table 3 shows that the Hausman Test probability value is 0.0000 , smaller than alpha $0.05(0.0000<0.05)$, so it can be concluded that the random-effect model is the suitable estimator. Table 4 shows the estimation results of the random-effect model with the GLS method for Equation (1).

Table 4. Estimation Results of the Random Effect Model with the GLS Method for Equation (1)

\begin{tabular}{ccccc}
\hline Variable & $\begin{array}{c}\text { Coefficient } \\
\text { Regression }\end{array}$ & Standard Error & t-statistic & Probability \\
\hline Constant & $5.61 \mathrm{E}+10$ & $2.42 \mathrm{E}+10$ & 2.320487 & 0.0210 \\
PAD & 0.515403 & 0.055136 & 9.347780 & 0.0000 \\
DAK & 0.250679 & 0.096010 & 2.610980 & 0.0095 \\
DAU & 0.156311 & 0.043353 & 3.605563 & 0.0004 \\
DBH & 0.573474 & 0.021624 & 26.52064 & 0.0000 \\
\hline
\end{tabular}

Table 4 shows that if PAD, DAK, DAU, and DBH do not change or equal zero, BM is 56.1 billion rupiahs with other variable assumptions is constant (ceteris paribus). If PAD increases by 1 billion, BM will increase by 0.515403 billion rupiahs. If DAK increases by 1 billion, BM will increase by 0.250679 billion rupiahs. If the DAU increases by 1 billion, BM will increase by 0.156311 billion rupiahs. If DBH increases by 1 billion, BM will increase by 0.573474 billion rupiahs, assuming other variables are constant (ceteris paribus).

Table 5 shows the estimation results of the random-effect model with the GLS method for Equation (2) as follows.

Table 5. Estimation Results of the Random Effect Model with the GLS Method for Equation (2)

\begin{tabular}{ccccc}
\hline Variable & Coefficient Regression & Standard Error & t-statistic & Probability \\
\hline Constant & 67.98327 & 0.627323 & 108.3704 & 0.0000 \\
BM & $6.21 \mathrm{E}-13$ & $1.25 \mathrm{E}-12$ & 0.495003 & 0.6210 \\
\hline
\end{tabular}

Table 5 shows that if capital expenditure (BM) does not change or is zero, community welfare (KM) is 67.98327 percent, assuming other variables are constant (ceteris paribus). If the BM increases by 1 billion, then KM will increase by 0.00000000000000621 percent, assuming other variables are constant (ceteris paribus). 


\section{Discussion}

The Effect of Locally-Generated Revenue (Pendapatan Asli Daerah-PAD) on Capital Expenditures (Belanja Modal-BM)

Table 4 shows that PAD has a positive and significant effect on the capital expenditure of districts/cities in Kalimantan. This result implies that if PAD increased, it would increase capital expenditures of districts/cities in Kalimantan. This result aligns with Andriani and Wahid (2018) and Heryanti et al. (2019) that stated that PAD has a positive and significant effect on capital expenditure. Therefore, it can be concluded that H1 is supported.

PAD is an income originating from a region or affiliated region. Fiscal decentralization allows regions to manage and regulate all government affairs by making regional policies to provide services, increase participation, initiative, and empower local communities to improve community welfare. The ability of one region to provide sources of income originating from the regions is highly dependent on the ability to realize the economic potential of the local area into forms of economic activity capable of creating regional revenues to finance economic development (Asari \& Suardana, 2018). Areas covered by adequate facilities and infrastructure will affect the level of productivity of the community. They will attract investors to invest in the area and, in the end, will increase income.

The Effect of Special Allocation Funds (Dana Alokasi Umum-DAK) on Capital Expenditures (Belanja Modal-BM)

Table 4 shows that DAK has a positive and significant effect on the capital expenditure of districts/cities in Kalimantan. It means that if DAK has increased, then the capital expenditure of districts/cities in Kalimantan will increase significantly. This result aligns with Pratiwi et al. (2018) and Saraswati and Ramantha (2018), which showed that DAK has a positive and significant effect on capital expenditure. Therefore, it can be concluded that $\mathrm{H} 2$ is supported.

DAK is intended to fund special activities that are regional affairs and constitute national priorities by the functions that are the manifestation of government duties in certain fields, mainly to fulfill the needs of standard public service and infrastructure. Initially, not all regions receive DAK allocations since it is reserve for regions with stipulated criteria. DAK originated for public service facilities, defense, security, economy, environment, health, tourism, housing, and public facilities.

\section{The Effect of General Allocation Funds (Dana Alokasi Umum-DAU) on Capital Expenditures (Belanja Modal-BM)}

Table 4 shows that DAU has a positive and significant effect on capital expenditure on districts/cities in Kalimantan. This result interpreted that if DAU has increased, the increase in capital expenditure of districts/cities in Kalimantan will increase significantly. This result aligns with Eksandy et al. (2019) and Fatimah et al. (2019) that DAU has a positive and significant effect on capital expenditure. Therefore, it can be concluded that $\mathrm{H} 3$ is supported.

In general, DAU is balancing funds. Balancing funds are budgeted to assist regions in local government funding and intended to reduce government funding sources between central and regional governments. DAU is a fund from APBN to equalize the financial capacity between regions to finance regional needs implementing decentralization. The government continues to develop a policy reformulation for the balance of development funds, especially for marginal areas. Development is carried out through capital expenditures to improve the welfare of the people in the area.

The Effect of Profit-Sharing Funds (Distribusi Bagi Hasil-DBH) on Capital Expenditures (Belanja Modal-BM)

Table 4 shows that DBH has a positive and significant effect on the capital expenditure of the district/city in Kalimantan. It means that if DBH increases, the capital 
expenditure of districts/cities in Kalimantan will experience a significant increase. The result aligns with Kadafi (2013), which stated that DBH has a positive and significant effect on capital expenditure. DBH is a source of regional revenue with the potential of being included as one of the fundamental assets of regional governments. Therefore, it can be concluded that $\mathrm{H} 4$ is supported.

The Effect of Capital Expenditures (Belanja Modal-BM) on Community Welfare (Kesejahteraan Masyarakat-KM)

Table 5 shows that capital expenditure does not affect the community welfare of districts/cities in Kalimantan. Therefore, it can be concluded that H5 is not supported. Capital expenditure is a budget issued to purchase fixed assets and other assets with a useful life of one period accounting stipulated by the government. The assets are used for the daily operations of a work unit, not for sale. The assets in question can be in the form of buildings, land, and others that are used for public services. Public services are very supportive of community welfare.

\section{CONCLUSIONS}

The results show that PAD, DAK, DAU, and DBH positively and significantly affect the capital expenditure of districts/cities in Kalimantan, while capital expenditure has no impact on community welfare. The implications of this study can be used by certain parties, especially for central and local governments in Kalimantan. The results of the data analysis are information for evaluating or making decisions by the government regarding the allocation of funds in Kalimantan. In addition, the results of this study will assist the community and public in Kalimantan to monitor regional finances and the financial performance of local governments. In connection with efforts to increase PAD, local governments in Kalimantan should encourage growth in the revenue sector to optimize regional income sources to support revenue. The policy to support this by encouraging Small and Medium Enterprises (MSMEs) growth by utilizing the National Self-Help Government Program (PNPM) Mandiri and a loan from the banking industry without collateral or lower interest rates. The local government should boost the growth of companies that will reduce unemployment which has implications for improving the welfare of the people in districts/cities in Kalimantan.

On the other hand, local government should implement regional autonomy related to investment in all sectors from property, agriculture, and commerce to increased production. Political stability and legal certainty associated with investment rules (regulations) contribute a significant role in encouraging an increase in the income sector. In the end, it will lead to the income sector of districts/cities in Kalimantan.

\section{REFERENCES}

Andriani, R. N. R., \& Wahid, N. N. (2018). Pengaruh Pendapatan Asli Daerah dan Dana Perimbangan Terhadap Kemandirian Keuangan Daerah (Studi Kasus pada Pemerintah Kota Tasikmalaya Tahun 2006-2015). Jurnal Akuntansi, 13(1), 30-39. http://jurnal.unsil.ac.id/index.php/jak/article/download/708/458

Asari, N. M. A., \& Suardana, K. A. (2018). Pengaruh Pendapatan Asli Daerah, Dana Perimbangan, dan Lain-Lain Pendapatan Daerah yang Sah pada Belanja Daerah. EJurnal Akuntansi, 25(2), 877-904. https://doi.org/10.24843/EJA.2018.v25.i02.p03.

Eksandy, A., Hakim, M. Z., \& Ekawati, E. (2019). Pengaruh Pendapatan Asli Daerah, Dana Alokasi Umum Dan Dana Alokasi Khusus Terhadap Belanja Modal (Pada Pemerintah Provinsi Banten Periode 2011-2015). Competitive, 2(2), 85-94. http://dx.doi.org/10.31000/competitive.v2i2.917

Fatimah, N. N., Nopiyanti, A., \& Mintuyuwono, D. (2019). Pengaruh Pendapatan Asli Daerah dan Dana Perimbangan Terhadap Belanja Daerah. Equity, 22(2), 197-214. http://dx.doi.org/10.34209/equ.v22i2.936

Heryanti, C. D., Wahidahwati, W., \& Suryono, B. (2019). Pengaruh Pendapatan Asli Daerah, 
Helma Malini | Factors Affecting Capital Expenditures and Community Welfare in Kalimantan

Dana Perimbangan dan Pertumbuhan Ekonomi terhadap Kinerja Keuangan Pemerintah Kabupaten/Kota di Provinsi Jawa Timur. Jurnal Analisa Akuntansi dan Perpajakan, 3(1), 98-116. https://doi.org/10.25139/jaap.v3il.1721

Kadafi, M. E. (2013). Pengaruh Pendapatan Asli Daerah dan Dana Perimbangan terhadap Belanja Modal (Studi Kasus pada Pemerintah Kota Bandung). Undergraduate Thesis. Universitas Widyatama Bandung.

Lamba, A., Novan, R., Lamba, R. A., \& Patma, K. (2020). The Impact of Economic Growth and Capital Expenditures in Supporting Quality Human Development. The International Journal of Social Sciences World (TIJOSSW), 2(2), 100-109. https://www.growingscholar.org/journal/index.php/TIJOSSW/article/view/69

Muda, I., \& Naibaho, R. (2018). Variables influencing allocation of capital expenditure in Indonesia. IOP Conference Series: Earth and Environmental Science, 126(1), 1-8. http://iopscience.iop.org/article/10.1088/1755-1315/126/1/012066/pdf

Pratiwi, A., Nurlaela, S., \& Chomsatu, Y. (2018). Pengaruh Pendapatan Asli Daerah, Dana Perimbangan dan Belanja Pegawai Terhadap Belanja Modal Pemerintah Kota $\begin{array}{llll}\text { Surakarta. Jurnal Ekonomi Paradigma, 19(2), } & \text { 105-112. }\end{array}$ https://journal.uniba.ac.id/index.php/PRM/article/download/14/14

Rostow, W. W., \& Rostow, W. W. (1990). The Stages of Economic Growth: A NonCommunist Manifesto. Cambridge University Press.

Sagar, A. D., \& Najam, A. (1998). The human development index: a critical review. Ecological Economics, 25(3), 249-264. https://doi.org/10.1016/S09218009(97)00168-7

Saraswati, D., \& Rioni, Y. S. (2019). Pengaruh Pendapatan Asli Daerah, Ukuran Pemerintah Daerah, Leverage, Terhadap Kinerja Keuangan Pemerintah Daerah. Jurnal Akuntansi Bisnis dan Publik, 9(2), 110-120.

Saraswati, I. A., \& Ramantha, I. W. (2018). Pengaruh Pendapatan Asli Daerah terhadap Pertumbuhan Ekonomi dengan Belanja Modal dan Investasi Swasta sebagai Pemoderasi. E-Jurnal Akuntansi, 24(1), 662-686. https://jurnal.pancabudi.ac.id/index.php/akuntansibisnisdanpublik/article/view/ $462 / 437$

Statistics Indonesia (2019). Data dan Informasi Kemiskinan Kabupaten/Kota Tahun 2018. Jakarta: Badan Pusat Statistik.

Sugiyono. (2014). Metode Penelitian Kuantitatif, Kualitatif, dan R\&D. CV Alfabeta.

Syafira, L. (2020). Pengaruh Pendapatan Asli Daerah (PAD), Dana Alokasi Umum (DAU), Dana Alokasi Khusus (DAK), Dana Bagi Hasil (DBH) dan Belanja Modal Terhadap Indeks Pembangunan Manusia pada Kabupaten/Kota Provinsi Sumatera Utara. Undergraduate Thesis. Universitas Negeri Medan.

Verspagen, B. (2005). Innovation and Economic Growth. In The Oxford Handbook of Innovation.

Wulandari, E., Wahyudi, M., \& Rani, U. (2018). Effect of Original Local Government Revenues, General Allocation Funds, Special Allocation Funds, Share Funds, Other Legal Revenues, Budget Surplus/Deficit to Human Development Index Through Capital Expenditures: Case Study of Regencies/Municipalities in Indonesia. Review of Integrative Business and Economics Research, 7(2), 125-137. http://buscompress.com/uploads/3/4/9/8/34980536/riber_7-s2_h17-129_125137.pdf 